\title{
Frenchifying the Frontier: Transnational Federalism in the Early West
}

\author{
Keri Holt \\ Utah State University
}

he antebellum West was a hotbed of literary activism. Western presses published
more than one hundred local newspapers and literary magazines from the late
1820s through the 1850s. Cities such as Vidalia, Lexington, Marietta, New Orleans, and Cincinnati were thriving literary centers, boasting numerous bookshops, libraries, theaters, and literary societies, including the Semi-Colon and Buckeye clubs of Cincinnati, where members exhibited their western pride by discussing the work of local authors while drinking beverages from buckeye bowls. ${ }^{1}$ The "West" at this time was located much closer east and south than the West we know today. It encompassed, roughly, the states of Ohio, Indiana, Illinois, Kentucky, Tennessee, and the Mississippi Valley region of present-day Louisiana, Arkansas, and Alabama. Anxious to assert a regional identity and sense of solidarity within the rapidly expanding nation, residents of this region pushed for the development of distinctly western literary culture, capable of representing, as one periodical editor put it, "the slight but perceptible shades of difference, and the visible particularities of national character, which our peculiar origin, physical circumstances, and moral condition have imposed upon us." 2

In celebrating these local "particularities," however, western advocates had to walk a fine line between asserting their regional distinctiveness and affirming their commitment to the nation. To avoid charges of sectionalism, western writers and editors often drew on the language of federalism to justify their regional focus, arguing that the development of a strong western community was a complement to national unity, rather than a threat to it. "He who would attempt to portray the American character, must draw, not a single portrait, but a family piece containing several heads," wrote James Hall, the 
prominent Cincinnati writer. "In each would be discovered some strong lines common to all . . but each would have a shade or cast of expression peculiar unto itself." ${ }^{3}$

How, then, did writers represent the West as part of this federal American family? What tactics did they use to portray the West's "peculiar shades," while also showing its "lines common to all"? Hall's work can help answer these questions. Originally from Philadelphia, he began his literary career writing for Joseph Dennie's well-known literary magazine, The Port-Folio, where he published alongside writers such as Charles Brockden Brown and Washington Irving. Following the successful publication of his travel narrative, Letters from the West (1822), Hall settled permanently in the Ohio Valley, where he quickly became one of the West's leading literary voices. Hall edited and published the first western literary annual, the Western Souvenir, in 1829. He also edited two of the West's most successful literary magazines, the Illinois Monthly Magazine and the Western Monthly Review. He regularly published and promoted western writers in his periodicals and was among the most vocal and influential advocates for western literature. In addition, he continued to publish a great deal of his own short fiction, which appeared in both western and eastern periodicals-including the Cincinnati Mirror, the New-York Mirror, and the Boston-based Literary Bouquet. The collected editions of his short stories, Legends of the West (1832), The Soldier's Bride, and other Tales (1833), and Tales of the Border (1835) —all published by a major publishing house in Philadelphia—brought him an even larger audience. Far from existing as a marginal literary figure during his time, Hall enjoyed a national reputation during the 1830s and 1840s, second only to Washington Irving's short stories. ${ }^{4}$

Given the national popularity and critical reception of his fiction, Hall's depictions of the West had a significant influence on the public imagination. One of the most definitive features of his work was his portrayal of the West as it existed in the past, and he regularly drew on the colonial history of the Ohio and Mississippi regions to assert the West's distinctive character. The majority of his stories are set during the French colonial past, and, as we shall see, they present what might best be described as a "Frenchified" vision of the region. Rather than providing a historically credible portrait, Hall's work typically conveys the region's "Frenchness" through stereotyped references to French foods, fashions, and phrases and characters who speak with broken accents.

Edward Watts has explored Hall's fictional recreations of the French colonial West, arguing that western writers used these constructions to critique the Anglo-centric, imperialist attitudes of the eastern United States. By recreating this French colonial history, Watts argues, writers like Hall "used the French frontier to express their discontent with and dissidence from the emergent 'Roman imperialism' of the United States." In 
the act of inviting readers to orient the western states in relation to non-English colonial tradition, he writes, "the memory of the French was used to imagine a nation . . . less greedy, less racist, less aggressive." ${ }^{5}$ Like Watts, I am interested in Hall's rhetorical use of French colonial history. But rather than looking at these stories in oppositional terms-as a western critique of eastern attitudes and policies—these stories can be read as an attempt to tie the nation more closely together by asserting and defending a federal conception of national unity.

Recognizing the federal dimensions of Hall's transnational tactics becomes easier if we consider his work in the context of the late 1820s and early 1830s when most of his work was published. During these years, the meaning of federal unity was a matter of increasingly contentious debate. The ongoing expansion of the nation, combined with divisions sparked by the War of 1812 and arguments over how best to legislate slavery, national tariffs, and interstate transportation, raised serious questions about the relationship between the states and the national government. ${ }^{6}$ The South Carolina nullification crisis brought these arguments to a head in the early 1830s as political leaders debated whether a state had the authority to nullify Congressional law. At stake in the nullification debates were two competing visions of the federal United States. On the one hand was a view of the United States as a union of semi-autonomous states, each retaining a strong degree of local authority. On the other hand was a more consolidated view, where the United States was understood as a union of like-minded citizens rather than separate states. Daniel Webster aptly summarized these competing national visions in his famous debates with southern senator Robert Hayne in 1830. "This leads us to inquire into the origin of this government and the source of its power," Webster stated. "Whose agent is it? Is it the creature of the state, or the creature of the people?"7

It is in the context of this question - whether the United States was to be perceived as a union of people or union of states-that I want to read Hall's Frenchifying literary tactics. By recreating the West's French colonial past, his stories argue for the importance of maintaining a sense of clear and bounded regional differences within the nation. At the same time, he carefully constructs his French colonial fictions to portray the West as a place that is different, yet also compatible with the history and culture of the nation as a whole. By thus portraying the West in relation to its French colonial past, Hall's transnational western tales ultimately assert the possibility of imagining a successful federal nation in the present.

Hall, of course, was not the inventor or sole practitioner of these transnational literary tactics. More than a decade earlier, Irving (a close friend of the Hall family) drew on the Dutch colonial history of New York to remind readers of "a period . . . almost 
a terra incognita in history." ${ }^{\prime 8}$ For Irving, recreating this Dutch colonial history offered readers a chance to gain a better appreciation for the "popular traditions" and "curious and racy customs" of the New York region, while also providing a means of reflecting on contemporary politics..$^{9}$ Such recreations of local history, he wrote, also had the potential to bolster a sense of national pride or "home feeling," providing readers with "a convivial currency" that can "link our whole community together in good-humor and good-fellowship."10

Subsequent writers explored the nationalist potential of colonial history even further through the genre of the historical romance. Exemplified by the work of James Fenimore Cooper's The Last of the Mohicans (1826) and The Prairie (1827), and Catherine Sedgwick's Hope Leslie (1827), such novels turned to the colonial past to emphasize the diversity of the nation's history. Within these novels, the United States emerges as a nation defined not by a singular, Anglo-American narrative but by a complex "compendium of histories" involving interactions between English, Native American, French, Spanish, and mixed-race communities. ${ }^{11}$

Hall's fictional recreations of the French colonial West are clearly part of this literary tradition. However, his regional politics distinguish his use of western colonial history. Although writers like Irving, Cooper, and Sedgwick did, in fact, focus on regional histories in their novels, their work was primarily invested in fostering a national literary culture, rather than defining and defending a particular region or set of regional aesthetics. ${ }^{12}$ In contrast, Hall's transnational histories were meant, first and foremost, to assert the West as a distinct yet integral part of the nation. Other western writers, among them Timothy Flint, Morgan Neville, and William Gallagher, also drew on the West's transnational colonial histories to define its distinctiveness. In examining their use of the past, it is important to foreground the complicated relationship between their regional and nationalist agendas, which, in turn, provides a new context for examining the regional politics of antebellum historical fiction, writ large. ${ }^{13}$

This western historical fiction also offers new avenues for transnational literary analysis. The transnational turn in U.S. literary studies has produced a wealth of influential scholarship. In exploring how U.S. history and culture have been shaped by "constant but critical interaction[s] with the global," scholars have understandably focused on interactions across national borders, interpreting U.S. literary and cultural texts in relation to trans-Atlantic or trans-hemispheric paths of influence and exchange. ${ }^{14}$ Of equal importance, however, are the many transnational engagements that occur within the nation's borders, exemplified by the French colonial focus of writers like Hall. Tom Lutz has recently argued for the importance of recognizing local spaces as "cosmopolitan 
vistas," where different national and cultural experiences intersect within a seemingly bounded space. ${ }^{15}$ By thus characterizing regions as a crossroads of "alternating cultural visions," Lutz's work encourages scholars to view regions like the antebellum West as a kind of interior borderland, where transnational encounters can be traced within the United States. ${ }^{16}$ Anthony Appiah's concept of "rooted cosmopolitanism" likewise provides a useful theoretical tool for examining how different national and cultural experiences and affiliations can find expression within a single locality (such as antebellum Ohio), which might, on the surface, seem far removed from global movements or international influences or affiliations. ${ }^{17}$

Scholars such as Ned Watts and Eric Hinderaker have made important strides in examining the West as a site of domestic transnationalism, drawing on comparative and postcolonial methods to show how regional studies can illuminate the "strikingly complex international legacy and presence" of the United States. ${ }^{18}$ As a country that grew out of territories that were claimed at various points by many nations, the United States has a diverse international history, and Hall's Frenchified western narratives provide an excellent starting point for examining the transnational dimensions of antebellum western literature. Focusing specifically on two of Hall's most popular western stories, "The Legend of Carondolet; or, Fifty Years Ago" (1830), and "The French Village" (1828), this article shows how transnational narratives were deeply implicated not just in defining a distinctive western region, but in defending the federal structure of the nation as a whole.

\section{“The Legend of Carondolet; Or, Fifty Years Ago"}

Published in 1830 and set in the Mississippi Valley region during the 1780s, "The Legend of Carondolet; or, Fifty Years Ago" exemplifies the transnational and, ultimately, federal dimensions of Hall's fiction. The story first appeared in the Vandalia-based Illinois Monthly Magazine, circulating almost exclusively among western audiences. In 1832 it was reprinted in Hall's short story collection Legends of the West, a collection that enjoyed popular and critical success in eastern and western literary markets." ${ }^{19}$ The publication dates of the story are worth noting, as they coincide with the increasingly divisive debates surrounding the South Carolina nullification crisis between 1828 and 1832. Hall regularly covered this controversy in the Illinois Monthly Magazine, and he used the crisis as an occasion to express his views about the limits of regional pride and autonomy. ${ }^{20}$ In July 1832, for instance, he published an article that, while somewhat sympathetic to South Carolina's position, nevertheless criticized the state for the divisiveness of its actions. Although the article acknowledges that the people of South Carolina have "grounds for 
complaint" regarding the national tariff of 1828, it eventually condemns the state legislature for the "self-interested" character of their response. Arguing that South Carolina's legal action threatens to "break up the Union . . . into as many separate independent, hostile governments," the article urges western readers to embrace more moderate forms of regional expression, such that "every link of the golden and, we hope, perpetual chain of the Union will be grasped as firmly by the citizens of the West as of the Atlantic." ${ }^{21}$

This image of the union as a chain, made up of separate links bound together, provides a useful trope for considering the regional and nationalist politics at stake in "The Legend of Carondolet; or, Fifty Years Ago." Set in the 1780s, the story invites readers to imagine the nation in the early years of its independence, when much of the West was still under the authority of the French crown. The tale begins in a small New England town, where the protagonist Timothy Eleazar Tompkinson, "the hopeful heir of a worthy mariner" has lived his whole life under the watchful care of his aunt, "the worthy Miss Fidelity Tompkinson." Industrious, practical, and plain-spoken, Timothy Eleazar emerges as a quintessential Yankee type, an identity further reinforced by the constant repetition of his regionally-resonant Protestant name. ${ }^{22}$ Initially poised to pursue a life close to home, his plans change when his father dies unexpectedly. Free to choose a new future for himself, he leaves New England to "roam at large over the wide expanse of his native country," eventually heading west toward the region of Missouri. ${ }^{23}$

As soon as Timothy Eleazar sets out, the narrator interrupts the story to remind readers that they will be looking at the West as it existed in the past, back when the territory was still a French territory:

Here I must leave my hero for the present, and ask the gentle reader to accompany me to the pleasant village of Carondolet, or as it is more commonly called, Vuide Poche, on the margin of the Mississippi. Although now dwindled into an obscure and ruinous hamlet, it was then the goodly seat of a prosperous community. (109)

Within this transitional paragraph, the narrator invites readers to replace their current view of western states with an earlier picture of the region as a thriving French colonial community. The narrator's reference to the two different names of this village-one formal (Carondolet) and the other colloquial (Vuide Poche)—evokes the story's recovery of the region's lost colonial character. Although both names mark its colonial history (Carondolet being the name of the Spanish colonial governor in the Louisiana territory, and Vuide Poche highlighting the French claims to the region), the narrator's decision use the village's colloquial name reflects the story's emphasis on recalling a largely forgot- 
ten past. Much like its name, which means "empty pockets," the village of Vuide Poche exists as an empty space in the current American landscape ("now a ruinous hamlet") that this story is meant to fill.

The narrator then goes on to describe the residents of Vuide Poche, as well as the French colonial culture and government of the region:

The inhabitants presented, I suppose, a fair specimen of the French peasantry, as they existed in France, previous to the first revolution. ... Though subject, at the date of our tale, to a foreign king, they were as good republicans as if they had been trained up in one of our own colonies. They knew the restraints and distinctions of a monarchy only by report, practicing the most rigid equality among themselves, and never troubling their heads to enquire how things were ordered elsewhere. The French commandants and priests who ruled in their numerous colonies, had always the knack of giving a parental character to their sway, and governed with so much mildness that the people never thought of questioning either the source or extent of their authority; while the English invariably alienate the affections of their colonists by oppression. The inhabitants of Vuide Poche were all plebeians; a few, who traded with the Indians, had amassed some little property; the remainder were hunters and boatmen-men who traversed the great prairies of the west and traced the largest rivers to their sources. (110-11)

In recalling this lost French history, the passage highlights differences between the colonial heritage of the eastern states and that of the western territories. In contrast to the Protestant, English-speaking world of New England where farming, seafaring, and manufacturing are common, the western territory is home to French-speaking Catholics who earn their living by hunting, fishing, and trapping. On a political level, the colonial government of the West, described as "mild" and "parental," also pointedly contrasts with that of the English, who "invariably alienate[d] the affections of their colonists by oppression" (111). Through this description, the West emerges as a region rooted in a more just and benevolent tradition of government; by contrast, the eastern states arose from a history of violence and oppression. Such a distinction is important, given the extent to which nationalism was so closely linked to the American Revolution. The rebellion of the colonies against the English crown was a powerful uniting force within the early nation, and many worried that this sense of unity and shared national origins would erode as states that did not share this revolutionary history were admitted to the union. By describing the West as a region shaped by a more liberal political history than that of the eastern states, this passage accounts for the West's lack of a shared revolutionary history in a way that nevertheless affirms the region's connection to good governance. ${ }^{24}$ 
Although much of this description highlights differences between the East and West, this passage ultimately suggests that the colonial history of the West is compatible with the founding ideals of the United States, particularly regarding the values of just governance, liberty, equality, and independence. The residents of Vuide Poche, for instance, are described in the excerpt above as "good republicans, as if they had been trained up in one of our own colonies," sharing the same belief in civic representation and social and political equality ("they were all plebeians") as the citizens of the founding American states. Although technically subject to the French crown, westerners have a strong sense of autonomy and independence from it. Taking charge of their local affairs, the French villagers "knew the restraints and distinctions of a monarchy only by report, practicing the most rigid equality among themselves, and never troubling their heads to enquire how things were ordered elsewhere" (110). The idyllic image of the republican French frontier governed by a benevolent French crown is, of course, a fiction. To focus on the historical accuracy (or, rather, inaccuracy) of this description, however, is to miss its rhetorical point. By inviting readers to look back and envision the West as a protorepublican community in the 1780 s, Hall creates a historical narrative that makes it easy to integrate the history of the West into the foundational history of the United States. Through this reconstructed French history, Hall supplies readers with a cultural memory that asserts the national legitimacy of the West as part of his present day United States.

The story continues to assert the West's compatibility with the founding history of the nation by depicting Timothy Eleazar's transformation from a classic Yankee into a Frenchified westerner. Upon arriving in Vuide Poche, he meets Monsieur Dunois, "a round-faced, laughing Frenchman ... [with] that mahogany tinge of complexion which belongs to this region" (111). The narrator relates their exchange:

\footnotetext{
"Pray sir," said Timothy Eleazar, with his best college bow, can you direct me to a tavern?"

"Tavern! vat you call? Eh? Oh la! d'auberge - no, Monsieur, dere is no tavern in Vuide Poche."

"This is awkward enough—what shall I do? My horse must be fed, and I am almost starved."

"Eh bien! You will have some ros bif, and somebody for eat your cheval? N'est ce pas?"

"I need food and lodging and know not where to go."

"Fude! Vat is fude, Marie? Ah ha! Aliment. Sacre! Monsieur is hungry! Loge! Here is ver good place, chez moi. You shall stay vid me. Ver good loge here, and plenty for eat you, et votre cheval." (113)
}

The stand-off between the two characters clearly displays the differences between the language and customs of New England and the French colonial West. Stand-offs 
between different regional types were popular in antebellum regional writing, where regional characteristics and accents were embellished to heighten the comic dimensions of each. Timothy Eleazar speaks only English, while M. Dunois's first language is French, and he has difficulty translating some of Timothy Eleazar's terms. The polite formality of Timothy Eleazar's speaking style contrasts with M. Dunois's much louder, more exclamatory demeanor, and this exaggerated comparison between the reserved Yankee and the boisterous Frenchman illustrates another separation between the East and West. ${ }^{25}$ Mike Featherstone notes, however, that there is more than just humor at stake in these performances. Although such representations often were overly simplistic, these stylized performances provide a "symbolic repertoire" for defining regional characteristics in the public imagination. ${ }^{26}$ In this regard, while the contrast between "zee ver French" M. Dunois and the upright Timothy Eleazar might seem overly staged and stylized, the exaggerated nature of their exchange provided a useful shorthand for defining and insisting upon real differences between them. Although their respective regions might have compatible histories and values, the exchange between these characters ensures that they will be perceived as distinct and separate cultural spaces. ${ }^{27}$

Significantly, the story's emphasis on these differences does not lead to division or conflict. While regional sketches of the 1820s and 1830s often asserted the superiority of one area over another-the industrious Yankee versus the indolent Southerner, the witty westerner versus the uptight Yankee-in this example, the Yankee and the western Frenchman are not at odds with one another. ${ }^{28}$ Although the two men speak and act differently, they find common ground for communicating. As the story proceeds, Timothy Eleazar discovers he can adapt to the language and customs of Vuide Poche without necessarily compromising his own Yankee characteristics. Instead of directing his practical and steady habits to a career at sea, he becomes a hunter and river boatman like his fellow villagers, and his "hunting excursions and expeditions upon the water, and his skill in the management of a boat, as well as his courage and address in every emergency soon gained him friends" (118).

In addition to earning the admiration of the French westerners, Timothy Eleazar comes to admire life in Vuide Poche as well. He is particularly drawn to "the harmony and apparent unity both of feeling and interest which bound this little community together," and he describes this unity in terms that echo federal sentiments. "They were like a single family," he observes, "their hearts beat in unison 'as the beat of one man,' [and] though some were poorer than others, they all mingled in the same dance" (114). These images portray the unity of Vuide Poche as the sum of its components. Its inhabit- 
ants behave like a family whose multiple hearts "beat as one" or as individuals linked in a dance, which, in turn, evokes the imagery and rhetoric used to describe the nation's federal unity during the late eighteenth and early nineteenth centuries. ${ }^{29}$ Ultimately, this sense of unity, combined with his successful adaptation to the customs and lifestyle of the region, convinces Timothy Eleazar to settle in Vuide Poche permanently. "All this chimed so well with the feelings of Mr. Timothy Eleazar Tompkinson," the narrator reports, "that he resolved forthwith to engraft himself upon this vigorous and cheerful stock" (114).

The verb "engraft," which involves creating a new identity out of two different but compatible components is important because it emphasizes the composite character of Timothy Eleazar's new identity. By "engrafting" himself onto this community, he combines his New England character with his new western habits to forge an identity made up of both experiences. The republican values and proto-federal unity that he finds in Vuide Poche provide the grounds for forging this connection, and on the basis of these shared principles, he can adopt a whole new language, profession, and set of customs while still sharing the same values of equality and federal unity of his Yankee countrymen. By the end of the story, Timothy Eleazar becomes "as swarthy as his neighbors," happily "wearing a capot and smoking a short pipe" on the porches of Vuide Poche, while still remaining recognizable as an American character-and indeed the narrator continues to refer to him as one throughout the story (120).

The narrative does not conclude, however, with this image of Timothy Eleazar as a fully assimilated, river-navigatin', French-speakin' westerner. Instead, it ends with the return of his aunt, Miss Fidelity Tompkinson, who moves west to take up residence in her nephew's home. She serves as a permanent reminder of his New England heritage and represents its fundamental differences with the West. "No one would have suspected that he was not a native," continues the narrator, "had it not been for his aunt, the worthy Miss Fidelity Tompkinson, who occupied the best room in his mansion, and who absolutely refused, though life, to eat gumbo soup, to speak French, or to pay any reverence to that respectable man, the priest" (120).

By ending with the return of Aunt Fidelity, "The Legend of Carondolet" argues that the United States is not a nation that can be represented by just one set of regional experiences or identities. Although Timothy Eleazar eagerly embraced the French characteristics and culture of the West, his aunt refuses follow his example. Even though the history and customs of the West might be compatible with New England, for Aunt Fidelity this compatibility is not a compelling reason for her to change, and she remains true to her New England roots. Despite her refusal to adapt, however, she lives as comfort- 
ably in Vuide Poche as her nephew and is accepted as a steadfast New Englander in the midst of the French and Catholic West. This final image of the Tompkinson household, occupied by the capot-wearing Timothy and gumbo-eschewing Aunt Fidelity, presents readers with a compelling model of federal unity. By showing how the French history and culture of the West can be incorporated into the nation while, at the same time, acknowledging that all citizens of the nation do not need to share the same cultural histories and experiences, "The Legend of Carondolet" argues that regional differences can coexist in a single (national) household without compromising or disrupting its unity as a whole. In other words, citizens from all parts of the United States can retain a sense of national unity, even if they don't eat the same foods, share the same histories, or even speak the same language.

\section{"The French Village"}

While "The Legend of Carondolet" focuses on the national compatibility of a FrenchAmerican cultural history, Hall's 1828 short story, “The French Village," presents a more critical view of the dangers of erasing that history. Set shortly after the Louisiana Purchase, the story juxtaposes two different views of a French frontier village. One takes place shortly before annexation and another several years later, when "the jurisdiction of the American region and its beneficial effects were beginning to be widely disseminated." 30 By criticizing the loss of the region's distinct local character under the annexation policies of the United States, the story pushes readers to reject a homogeneous view of the nation and, instead, recall and preserve its diverse regional histories.

The initial descriptions of the village portray the West as culturally distinct, yet closely aligned with the values of the founding states. "[C]omposed, partly, of emigrants from France, and partly of natives-not Indians_-but bona fide French, born in America," the French villagers maintain a strong connection to their roots, "preserv[ing] their language, their manners, and their agility in dancing" (123). In addition to matters of manners and language, the French villagers are further distinguished from their eastern neighbors by their collaborative style of land management, where individual properties are "enclosed in a single fence, called the 'common field,' in which all worked harmoniously, though each cultivated his own acres," as well as by their peaceful relationship with local Native Americans (124).

It is worthy of remark, that the French have invariably been more successful in securing the confidence and affection of the Indian tribes than any other nation ... the French alone 
have won them to the familiar intercourse of social life, lived with them in the mutual interchange of kindness; and, by treating them as friends and equals, gained their entire confidence. This result, which has been attributed to the sagacious policy of their government, is perhaps more owing to the conciliatory manners of that amiable people, and the absence among them of that insatiable avarice, that boundless ambition, that reckless prodigality of human life, that unprincipled disregard of public and solemn leagues, which, in the conquests of the British and the Spaniards, have marked their footsteps with misery, and blood, and desolation. (123)

Although this description differentiates the colonial history of the West from the English and Spanish histories of the eastern and southern states, it aligns the West with the founding principles of the United States. Unlike the former British and Spanish colonies, which are marked by a legacy of violence, greed, dishonesty, and exploitation, the West emerges as a region with a political history of tolerance, equality, and respect for legal agreements-a description that, as Edward Watts has observed, "colors the French as more true to the values of the Revolution than the Anglos." ${ }^{31}$ Lest the connection between the French colonies and the principles of the United States remain too understated, the narrator later makes this link explicit by stating that the French westerners "enjoyed, to the full extent, those three blessings on which our declaration of independence has laid so much stress-life, liberty, and the pursuit of happiness" (123).

After aligning the French history of the West with the republican principles of the United States, the story emphasizes the importance of preserving that history within the nation. The story focuses on two visits to the region by a Yankee narrator who arrives in the village in the midst of a local celebration, which turns out to be the annual celebration of Carnival. "The notes of the violin and the groups of gaily attired people who thronged the street attracted my attention and induced me to enquire the occasion of this merriment," he writes, and to his surprise, he is immediately invited to take part by attending one of the local "king balls," which "strangers were always expected to attend without invitation" (130-31).

From this point forward, the narrator becomes an active and eager participant in all the Carnival events, doing his best to learn the necessary conventions as he goes along.

The ceremony was soon explained to me. On the first day of the Carnival, four selfappointed kings, having selected their queens, give a ball, at their own proper costs, to the whole village. In the course of the evening the queens select, in the manner described, the kings for the ensuing day, who choose their queens, in turn, by presenting the nosegay and the kiss. This is repeated every evening in the week; - the kings, for the time being, 
giving the ball at their own expense, and all the inhabitants attending without invitation. On the morning after each ball, the kings of the preceding evening make small presents to their late queens, and their temporary alliance is dissolved. (132)

Although the customs and rituals of the ball are clearly unfamiliar to him, his detailed descriptions highlight his interest and enthusiasm. Rather than feeling alienated or out of place, the narrator continually emphasizes how he is made to feel at home in the midst of these celebrations. "The moment I entered the room, I felt that I was welcome," he writes. "Not a single look of surprise, not a glance of more than ordinary attention, denoted me as a stranger or unexpected guest" (131). In fact, the narrator is so thoroughly integrated into the celebration that he is eventually crowned as one of the kings, a position he accepts with pleasure, remarking that "never did a king enjoy, with more delight the first fruits of his elevation" (131).

Crowning the narrator as one of the kings of the Carnival presents an interesting irony, given that the story is set at a time when the United States was declaring its sovereignty over the former French territory. The crowning of this new Yankee king is not staged as a moment of conquest, however. Instead, the narrator arrives at his title because of his willingness to subject himself to the customs of the French village and the will of the people. In short, he is a king only insofar as he submits to the cultural rules of the French villagers, and his respect and appreciation for them and their local customs eventually lays the ground work for building productive and cohesive relationships with his new French countrymen. On the basis of his positive experiences with the Carnival, he spends several more weeks in the town learning more about its local history and "peculiarities," which "amply repaid me in the many friendships I gained" (132).

The narrator's second visit to the village, which takes place several years later when "the jurisdiction of the American region, and its beneficial effects were beginning to be widely disseminated," presents a different scene (132-33). Again, his visit coincides with a local celebration. "As I drew near a volume of sounds burst upon me, such as defied all conjecture. Fiddles, flutes, and tambourines, drums, cow-horns, tin trumpets, and kettles, mingled their discordant notes with a strange accompaniment of laughter, shouts, and singing" (133). This time, however, the celebration is a "charivary," which, as the narrator soon explains, is "a custom that prevails among the American French, of serenading, at the marriage of a widow or widower, with such a concert as I now witnessed" (133-34).32 Although he identifies the charivary as an "American French" custom, the narrator soon realizes that this particular charivary is not being celebrated by local residents at all. Instead, the entire celebration is being led by a band of "new settlers" 
who had "witnessed" the ceremony "without exactly understanding its application" (134-35). As a result, although they mimic the elements of a charivary, they nevertheless misapply the tradition. Rather than celebrating the engagement of two widowed people, this particular charivary is celebrated in honor of the engagement of Monsieur Baptiste Menou and Mademoiselle Jeanette Duvall, two residents of the town who have never been married.

As the group of revelers arrives at his house to serenade him, M. Menou repeatedly tries to point out their mistake.

"Gentlemen!" expostulated the bridegroom, "for why you make this charivary for me. I have never been marry before-and Mam'selle Jeanette has never been marry before!" Roll went the drum! - Cow-horns, kettles, tin trumpets, and fiddles poured forth volumes of sound, and the mob shouted in unison.

"Gentlemen! pardonnez-moi-" supplicated the distressed Baptiste. "If I understand dis custom, which have long prevail vid us, it is vat I say—ven a gentilman, who has been marry before, shall marry de second time—or ven a lady have de misfortune to loose her husband, and be so happy charivary—but 'tis not so with Mamselle Duval and me. Upon my honor we have never been marry before dis time!" (134)

M. Menou tries to correct the crowd's mistaken use of the charivary, but his arguments fall on deaf ears. The pleasures and excitement of the celebration ultimately outweigh the revelers' interests in observing its original purpose, and so the charivary continues, loudly and raucously, by this "mob" of new residents "whose love of fun outstripped their veneration for ancient usages" (136).

M. Menou specifically characterizes the transformation of the charivary as a consequence of U.S. expansion. "Dis come for have d'Americain government to rule de countrie," he informs the narrator. "They make charivary for de old maid and de old bachelor" (135). Instead of representing the history and culture of the French residents, the charivary has been revised to satisfy the interests and expectations of the new settlers. In contrast, then, to the earlier example, where the narrator took care to respect the local conventions and protocols of the Carnival, this second visit criticizes the new U.S. settlers for appropriating and transforming this local celebration for their own purposes. This misuse of the charivary could be corrected if they were willing to learn more about the tradition and the history of the villagers. As is clear from M. Menou's futile attempts to educate the revelers on both these points, however, the new settlers are not interested in being faithful to the tradition; they are interested in the celebration only insofar as it enhances their own interests—in this case, their "love of fun" (136). 
The narrator soon discovers that charivary isn't the only aspect of life in the French village that has changed under the U.S. flag. "The old inhabitants . . had good reason to be alarmed," he writes, "for their ancient customs, like their mud-walled cottages, were crumbling to ruins around them, and every day destroyed some vestige of their former years" (136). The arrival of U.S. surveyors alters the physical space of the village as they begin "measuring off the whole country with the avowed intention, on the part of the government, of converting into private property those beautiful regions that had heretofore been free to all who trod the soil or breathed the air" (136). The appearance of "a "judge, a clerk, a sheriff, a courthouse, and a jail," further transforms the daily lives of the villagers, who now feel pressured to "enroll in the militia," "attend the court as jurors," and educate themselves about the "long list of offenses which [now] fell within their cognizance" (137). The Americanization of the region also ends the villagers' productive relationship with local Indian tribes, who, wary of U.S. policies, have "sold their hunting grounds" and moved further west, thus "depriv[ing] the village of its only branch of commerce" in the process (136).

The harsh terms in which the narrator describes the destruction of local property, commerce, and customs in the French village presents an extremely critical view of U.S. expansion. By characterizing it as a process that deforms and degenerates the lifestyle and history of the region, the story takes these eastern settlers to task for failing to acknowledge and respect the differences of the territories they acquire. Ultimately, these changes become so disruptive that most of the original residents decide to leave the region entirely, "shak[ing] their heads and declar[ing] that this was no longer the country for them" (136-37).

This story is not just a lament for a lost way of life, however. While the narrator clearly criticizes the expanding United States for eroding the French culture of the West, the departing villagers are also responsible, to some extent, for this erasure. The former residents' attempt to preserve their culture by establishing a new French settlement "among the sugar plantations of their countrymen to the south" only ensures that this French history and culture will have no future place within the United States (137). The flight of the French residents thus begs the question: How can regional communities preserve their diverse international cultures and histories while remaining within the boundaries of the United States?

The story provides a potential answer in the example of Monsieur Menou. In contrast to his fellow villagers who try to preserve their culture by withdrawing from the nation, M. Menou opts to remain and incorporate the regional French past into an 
American future. After failing to point out the mistaken application of the charivary, M. Menou gives up his objections and takes part in the celebration on its new terms: "Finding there was no means of avoiding the charivary, he with great good humor, accepted the serenade and, according to custom, invited the whole party into his house" (135). By remaining to remind new residents of the history of this tradition and mark its transformation, M. Menou ensures that this particular aspect of the village's French colonial heritage will continue, albeit in an Americanized form.

The story concludes with an image of M. Menou's new home, which he and his wife construct to replace their prior ones and decorate "in remembrance of old times." It is built "in the space between the [former] cottages of Baptiste and Jeannette" and evokes the French past and reflects their new American citizenship (138). In contrast to the homes of their neighbors, which "have fallen down," the Menou's new home strikes a balance between representing the region's older history and its new place within the United States. In this new home, framed by their former history, Baptiste Menou and Jeanette Duvall can remain as visible reminders of the past in the space of the present, "exhibiting in their old age, the same amiable character which, in early life, won for them the respect and love of their neighbors and of each other" (138).

Like the reconstructed home of M. Menou, James Hall's stories rebuild the French history of the West in order to keep its distinctive character visible for contemporary American readers. By inviting audiences to reread the West as a French cultural space, stories like "The French Village" and "The Legend of Carondolet" encourage readers to recall and embrace the often invisible transnational histories that make up the United States. In doing so, these stories also prevent readers from viewing the West as a blank space to be shaped by eastern policies and development. In this regard, we might also read Hall's work not just as a defense of federalism but as a critique of the policies of erasure and assimilation that shaped the nation's westward expansion.

In cautioning readers against the cultural losses and transformations that occur when the original settlers of a region are displaced, "The French Village" can also be read as a subtle critique of the Native American removal policies taking shape in the early 1830s. Joshua Bellin has examined how antebellum writers often engaged with the subject of Indian removal indirectly through more general narratives of "intercultural encounter." Arguing that it is "reductive to label as Indian stories only stories populated by Indians," Bellin provides a useful model for considering how Hall's story of transcultural encounter, displacement, and assimilation might also be read as a critical commentary on United States' Indian policy which, "even [if] not based on the facts of 
[Indian] interculturalism, are based in the fact of it." ${ }^{33}$ Hall, in fact, had a complex history of engaging with Native American issues, most notably with respect to his depiction of the Indian Hater, a violent figure that was popular in antebellum frontier fiction who systematically murders Indians in retaliation for the loss of his family. ${ }^{34}$ As a number of scholars have noted, Hall's stories typically present a more critical view of the Indian Hater than many of his contemporaries, objecting to the racial violence and imperialist entitlement inherent in his actions and sympathizing with the dispossession and abuse of his Indian victims.

In critiquing the figure of the Indian Hater, however, Hall's depictions of Native American life and culture remain problematic. His stories typically portray Indians in passive and primitive terms, as people in need of the protection and oversight of civilized white society. His sympathetic, yet paternalistic attitude toward Native Americans is exemplified, for instance, in his three-volume illustrated History of the Native American Tribes, which he co-authored with the superintendent of the Office of Indian Affairs, Thomas McKenney, in 1836. In the introduction, Hall presents a harsh condemnation of Indian policies in the United States, bluntly stating that "we believe our system of relations with the Indian tribes to be radically wrong and productive of a great wrong to them. ... Our government has not only failed to accomplish its benevolent purposes towards them, but has in fact done much positive wrong to them and to ourselves." 35 While Hall clearly objects to the "ruinous tendency" of current government policies, his comments also illustrate his belief that native tribes required the assistance of the United States government in order to survive. Throughout his career, he remained committed to the idea that nationally funded programs of assimilation were the best way to protect the interests of native peoples, writing in 1835 that "the march of the mind will never penetrate into our forests by the beat of the drum nor will civilization be transmitted in bales of scarlet cloth and glass beads." 36

Hall's paternalistic and assimilationist views toward Native Americans can be detected in his representation of the Menou family in the "The French Village." For as much as the story asserts the importance of preserving the region's French cultural past, in the end, Hall takes care to not to grant too much authority to the region's "native" residents. The former French residents must ultimately subject themselves to the authority of the (white, Anglo, eastern) United States in order to continue to represent their own history. The final image of the Menou's home as a semi-separate, French-commemorative space situated securely within the purview of the United States foreshadows John Marshall's 1831 designation of Native American tribes as domestic dependent nations. Despite his 
literary support for preserving the nation's regional and cultural diversity, Hall's federal vision did not extend to grant sovereign status to the different non-white communities. The federal diversity he wants to celebrate in defining the West ultimately involves containing and controlling the diverse communities already embedded there.

As sectional divisions and conflicts between local and national authority intensified, Hall's vision of the nation as a federal family, made up of different and well-defined regional communities, became increasingly compromised by the experiences of dispossession, exploitation, and racial injustice that accompanied westward expansion. In light of this history, Hall's early fiction ultimately highlights not so much the promise but the limits of the cohesive federal vision he sought to promote throughout the 1830s. In the end, the transnational regional tactics that once seemed so useful for imagining a united federal nation would prove unsustainable as citizens came to view local differences as a threat to national union, rather than a foundation of it.

\section{Notes}

1. Charles Frederic Goss, Cincinnati: The Queen City, 1788-1912 (Chicago: S.J. Clarke, 1912), 434.

2. Timothy Flint, "National Character," Western Monthly Review 1, no. 3 (July 1827): 133. W.H. Venable's Beginnings of Literary Culture in the Ohio Valley, Historical and Biographical Sketches (Cincinnati: Robert Clark \& Co., 1891) offers an extensive history of this western literary movement. For more contemporary studies of antebellum western literary culture, see Edward Watts, An American Colony: Regionalism and the Roots of Midwestern Culture (Athens: Ohio Univ. Press, 2002) and Daniel Aaron, Cincinnati, Queen City of the West (Columbus: Ohio Univ. Press, 1992).

3. James Hall, Letters from the West (London: Henry Colburn, 1828), 236.

4. Hall also published works of western history as well, including Sketches of History, Life, and Manners of the West (1835), A Memoir of the Public Services of William Henry Harrison of Ohio (1836), and History of the Indian Tribes of North America (1835-44) co-written with Thomas McKenney. For further information about Hall's literary career, see John T. Flanagan's James Hall: Literary Pioneer of the Ohio Valley (Minneapolis: Univ. of Minnesota Press, 1941), as well as Venable's “Judge James Hall. Soldier, Jurist, Author, Editor," in Beginnings of Literary Culture in the Ohio Valley, 361-85.

5. Edward Watts, In This Remote Country: French Colonial Culture in the Anglo-American Imagination (Chapel Hill: Univ. of North Carolina Press, 2006), 4.

6. John Quincy Adams noted the transformative effects of the Louisiana Purchase on the federal unity of the nation, writing that "it ma[kes] a Union totally different from that which the Constitution had been formed" (quoted in Everett Brown, The Constitutional History of the Louisiana Purchase: 1803-1812 [Berkeley: Univ. of California Press, 1920], 30). Useful discussions of these debates over federal unity in the context of expansion, the War of 1812, slavery, and national legislation can be found in Robert Ferguson, Law and Letters in American Culture (Boston: Harvard Univ. Press, 1987); 
David S. Reynolds, Waking Giant: America in the Age of Jackson (New York: Harper Perennial, 2009); and Sanford Levinson and Bartholomew Sparrow's edited collection, The Louisiana Purchase and American Expansion (New York: Rowman \& Littlefield, 2005).

7. Daniel Webster, "Speech to the Senate, January 26, 1830," Speeches of Hayne and Webster in the United States Senate (Boston: A.T. Hotchkiss \& W.P. Fetridge, 1853), 70. The Webster-Hayne debates were widely reprinted in U.S. newspapers, particularly Webster's "Second Reply to Hayne," which provided the clearest statements regarding the two competing visions of national unity at stake in the nullification crisis. For more on these debates see Harlow W. Sheidley, "The Webster-Hayne Debate: Recasting New England Sectionalism," The New England Quarterly 67, no. 1 (1994): 5-29; Stefan M. Brooks, Webster-Hayne Debate: An Inquiry into the Nature of Union (New York: Univ. Press of America, 2008); and Richard E. Ellis, Union at Risk: Jacksonian Democracy, States' Rights, and the Nullification Crisis (New York: Oxford Univ. Press, 1987).

8. Washington Irving, "The Author's Apology," A History of New York (New York: G.P. Putnam, 1853), xii.

9. Ibid., xiii. For Irving's use of history in relation to nationalism and political critique, see Jeffrey Scraba, "Quixotic History and Cultural Memory: Knickerbocker's History of New York," Early American Studies 7, no. 2 (Fall 2009): 389-425; and Jeffrey Insko, “Deidrich Knickerbocker, Regular Bred Historian," Early American Literature 43, no. 3 (2008): 605-41.

10. Ibid.

11. Geoffrey Rans offers a useful study of Cooper's plural accounts of history in Cooper's Leatherstocking Novels: A Secular Reading (Chapel Hill: Univ. of North Carolina Press, 1991), 70. Michael D. Bell likewise examines Sedgwick's focus on intercultural history in "History and Romance Convention in Hope Leslie," American Quarterly 22, no. 2 (Summer 1970): 213-21. For more extensive discussions of the diverse representation of history in the historical romance genre, see Harry B. Henderson's Versions of the Past: The Historical Imagination in American Fiction (New York: Oxford Univ. Press, 1974).

12. Cooper and Sedgwick directly address the nationalist focus of their work. In her preface to Hope Leslie, Sedgwick notes that "the ambition of the writer would be fully gratified if, by this work, any of our young countrymen, should be stimulated to investigate the early history of their native land" (Hope Leslie [New Brunswick: Rutgers University Press, 2003], 6). Likewise, Cooper writes of the way in which "awaken[ing] recollections of the past" can "elicit" national feelings (Notions of the Americans [Philadelphia: Carey, Lea, and Blanchard, 1835], 24). For more on the nationalist focus of their literary work, see Catharine Maria Sedgwick: Critical Perspectives, ed. Lucinda L. Damon-Bach and Victoria Clements (Boston: Northeastern Univ. Press, 2003), and Armin Paul Frank, "Writing Literary Independence: The Case of Cooper," Comparative Literature Studies 34, no. 1 (1997): 41-70.

13. Flint, Neville, and Gallagher wrote a number of stories that explored the French, Spanish, Dutch, Irish, and Native American histories of influence in the West, among them Neville's "The Exile of Mexico" (1831); Gallagher's “The Heiress of Rock Hollow” (1839); and Flint's “Jemima O'Keefy— 
a Sentimental Tale" (1828). See Venable's history of the literature of the Ohio Valley for a more detailed account of these authors and their work.

14. José E. Limón, "Border Literary Histories, Globalization, and Critical Regionalism," American Literary History 20, no. 1-2 (Spring-Summer 2008): 168. For an overview of the origins, development, and current scholarship in transatlantic and hemispheric literary studies, see Shelley Fisher Fishkin's 2004 address to the American Studies Association, published in The American Quarterly 57, no. 1 (March 2005): 17-57, as well as articles featured in Susan Manning and Andrew Taylor's Transatlantic Literature Studies: A Reader (Baltimore: Johns Hopkins Univ. Press, 2007), and Caroline Levander and Robert S. Levine's Hemispheric American Studies (New Brunswick: Rutgers Univ. Press, 2007).

15. Tom Lutz, Cosmopolitan Vistas: American Regionalism and Literary Value (Ithaca: Cornell Univ. Press, 2004), 31.

16. Ibid.

17. Taking issue with the idea that cosmopolitanism necessarily involves the "discarding of all local loyalties," Anthony Appiah argues that cosmopolitan perspectives are always influenced by lingering, transnational "allegiances" that invariably produce complex forms of identification or affinity. See The Ethics of Identity (Princeton: Princeton Univ. Press, 2005), 221.

18. Edward Watts, "The Midwest as a Colony: Transnational Regionalism," Regionalism in the Humanities, ed. Timothy R. Mahoney and Wendy J. Katz (Lincoln: Univ. of Nebraska Press, 2009), 168. See also Eric Hinderaker, "Liberating Contrivances: Narrative and Identity in Ohio Valley Histories," The Identity of the Midwest, ed. Andrew L.R. Cayton and Susan Gray (Bloomington: Indiana Univ. Press), as well as Hinderaker's Elusive Empires: Constructing Colonialism in the Ohio Valley (New York: Cambridge University Press, 1997). Scholars working in the areas of hemispheric studies and critical regionalism also emphasize the importance of recognizing transnational exchanges within national borders, as Limón argues in "Border Literary Histories, Globalization, and Critical Regionalism." Examples of this approach can also be found in the 2006 special issue of American Literary History on "Hemispheric American Literary History," 18, no. 3 (Fall 2006), as well as in Cheryl Temple Herr, Critical Regionalism and Cultural Studies (Gainesville: Univ. of Florida Press, 1996); Douglas Robert Powell, Critical Regionalism: Connecting Politics and Culture in the American Landscape (Chapel Hill: Univ. of North Carolina Press, 2007); and Robert Eric Livingston, “Global Knowledges: Agency and Place in Literary Studies," PMLA 116, no. 1 (2001): 145-57.

19. Favorable reviews of Hall's work appeared in American Quarterly Observer, American Monthly Magazine, New-England Magazine, New-York Mirror, Ariel, North American Magazine, Cincinnati Mirror, and Illinois Monthly Magazine, among others. For additional publication and reception information see Venable, "Judge James Hall," 361-85.

20. The nullification debates were followed closely in western newspapers and magazines as a whole, and westerners were divided on the issue. While many sympathized with the South Carolinians' efforts to assert their local authority, believing that the Southerners' actions were aligned with their 
own efforts to assert the regional distinctiveness of the West, others objected to South Carolina's tactics, believing that the state government went too far by giving local interests precedence over national concerns. See Douglas A. Irwin, "Antebellum Tariff Politics: Regional Coalitions and Shifting Economic Interests," Journal of Law \& Economics 51, no. 4 (Nov, 2008): 715-741, and Elizabeth Oliver Lee, "Reclaiming the American Revolution: The Kentucky and Virginia Resolutions and their Legacy," West Virginia History 1, no. 1 (March 2007): 104-05.

21. "The State of the South," Illinois Monthly Magazine. 2, no. 22 (July 1832): 473.

22. Jennette Tandy discusses how names were used to connote certain regional types, particularly regarding the biblical and Protestant-inflected names of the Yankee type. See The Crackerjack Philosophers in American Humor and Satire (Port Washington, N.Y.: Kennicat Press, 1925).

23. Hall, "The Legend of Carondolet," in The Indian Hater and Other Stories, ed. Edward Watts (Kent, OH: Kent State Univ. Press, 2009), 105-120, at 109. Further references to Hall's "The Legend of Carondolet" will be cited parenthetically in the text.

24. For further discussions of the role that representations of the American Revolution played in the development of nationalism, see Mitch Kachun, “From Forgotten Founder to Indispensable Icon: Crispus Attucks, Black Citizenship, and Collective Memory, 1770-1865," Journal of the Early Republic 29, no. 2 (Summer 2009): 249-86; Edward Tang, “Writing the American Revolution: War Veterans in the Nineteenth-Century Cultural Memory," Journal of American Studies 32, no. 1 (1998): 63-80; and Philip Gould, "Virtue, Ideology, and the American Revolution: The Legacy of the Republican Synthesis," American Literary History 5, no. 3 (Fall 1993): 564-77.

25. For more detailed discussion of the history of French cultural stereotypes in American literature and culture, see William L. Chew's introduction to National Stereotypes in Perspective: Americans in France, Frenchmen in America (Amsterdam: Rodopi Press, 2001).

26. Mike Featherstone, "Localism, Globalism, and Cultural Identity," Global / Local: Cultural Production and the Transnational Imaginary, ed. Rob Wilson and Wilmal Dissanayke (Durham: Duke Univ. Press, 1996), 55.

27. My analysis here draws heavily on Featherstone's discussion of the ways in which local residents simply mobilize "a repertoire of communal symbols, sentiments, and collective memories" to present a cohesive and recognizable image of itself for public consumption" (54-55).

28. Most regional sketches of the early nineteenth century, notes Walter Blair, sought to bolster local loyalties by asserting the superiority of one region over another. Figures such as "the Yankee, the backwoodsman, the New England bluestocking, the New York Dutchman, and the Southern aristocrat [provided] a fairly persistent contrast [for] pitt[ing] the Eastern seaboard against the back settlements" (158). For more on the conflicts and politics of antebellum regional humor, see Native American Humor, 1800-1900 (New York: American Book Company, 1937).

29. Eric Slauter provides an extensive discussion of metaphors used to depict the federal unity of the early republic in his chapter titled "Making a Government of Laws" in The State of the Work of Art (Chicago: Univ. of Chicago Press, 2009), 39-86. 
30. Hall, "The French Village," in The Indian Hater and Other Stories, ed. Watts, 121-138, at 133. Further references to Hall's "The French Village" will be cited parenthetically in the text.

31. Watts, Remote Country, 87.

32. For more on the cultural history and prevalence of charivary as a French-American folk tradition, see Brian D. Palmer, "Discordant Music: Charivaris and Whitecapping in Nineteenth-Century North America," Labour / Le Travail 3 (September 1978): 5-62.

33 Joshua David Bellin, The Demon of the Continent: Indians and the Shaping of American Literature (Philadelphia: Univ. of Pennsylvania Press, 2000), 27. Lucy Maddox also discusses the ways that Indian and Native American issues often appear in indirect or "elusive" ways in antebellum fiction, a rhetorical condition she interprets as "the difficulty white Americans had in conceiving of living Indian people as belonging to nations-either their own Indian nations or to the new republican nation that white America was consciously constructing for itself," in Removals: Nineteenth-Century American Literature and the Politics of Indian Affairs (New York: Oxford Univ. Press, 1991), 9-10.

34. For critical discussions of the Indian Hater and Hall's representation of this figure, see Maddox, 83-87; Watt's introduction to The Indian Hater and Other Stories, xvi-xvii; and Roy Harvey Pearce's article, "Melville's Indian Hater," PMLA 67, no. 7 (Dec. 1952): 942-48.

35. Hall, History of the Indian tribes of North America, vol. 3 (Philadelphia: E. Biddle, 1835-44), 103-104. For more about Hall's later involvement with Native American issues, see Watts's chapter on "Monstrous Exceptions: Anglo Patriarchs, French Families, and Métis Americans" in In This Remote Country. For more on Hall and McKenney's work, see Christopher Lane, "A History of McKenney and Hall's History of the Indian Tribes of North America," Imprint: Journal of the American Historical Print Collectors Society, 27, no. 2 (2002): 2-15.

36. Hall, Sketches of the History, Life, and Manners in the West, vol. 1 (Boston: Harrison Hall, 1835), 112. 